\title{
Structural Protein Gene
}

National Cancer Institute

\section{Source}

National Cancer Institute. Structural Protein Gene. NCI Thesaurus. Code C20744.

A gene that encodes a protein with a chief function as part of a physical structure within a cell. This is in contrast to genes that encode proteins with a function that is enzymatic or regulatory. 